\title{
ARTIGOS
}

\section{A INFLUÊNCIA DA VERTICALIZAÇÃO NA SENSAÇÃO TÉRMICA URBANA: ESTUDO DE CASO EM VILA VELHA/ES}

THE INFLUENCE OF VERTICALIZATION ON URBAN THERMAL SENSATION: CASE STUDY IN VILA VELHA/ES

\section{JULIANA SILVA ALMEIDA SANTOS | UFES}

\section{ALINE SILVA SAUER, M.SC. UCL}

\begin{abstract}
RESUMO
O crescimento acelerado dos centros urbanos vem provocando sérias transformações no uso do solo e no meio natural, gerando alterações no microclima destas áreas e impactando diretamente no conforto ambiental da população. Assim, o objetivo da pesquisa foi avaliar a possível influência da verticalização no microclima urbano e na sensação térmica dos transeuntes, a partir de um estudo comparativo entre quatro bairros próximos à orla de Praia de Itaparica em Vila Velha/ES. A metodologia partiu de revisão bibliográfica e consistiu na elaboração de um estudo de caso para monitoramento climático simultâneo à aplicação de um instrumento de avaliação da sensação térmica. Os resultados indicaram que a verticalização exerce influência sobre as variáveis climáticas e por consequência interfere na sensação térmica dos transeuntes.
\end{abstract}

PALAVRAS CHAVE: Verticalização; Microclima Urbano; Sensação Térmica; Conforto Ambiental

\begin{abstract}
The accelerated growth of urban centers has been causing serious changes in the soil and natural environment, generating changes in the microclimate of these areas and directly affecting the environmental comfort of the population. Thus, this research aimed to evaluate the influence of verticalization in the urban microclimate and on the thermal sensation of the passerby, based on a comparative study between four neighborhoods near the Praia de Itaparica coast in Vila Velha/ES. The methodology started from a literature review and consisted in the elaboration of a case study for climate monitoring and application of an instrument to evaluate the thermal sensation. The results indicated that the verticalization exerts influence on the climatic variables and consequently interferes in the thermal sensation of the passerby.
\end{abstract}

KEY WORDS: Verticalization; Urban Microclimate; Thermal Sensation; Environmental Comfort 


\section{INTRODUÇÃO}

O crescimento acelerado dos centros urbanos e o processo de adensamento das cidades vêm provocando sérias transformações no uso do solo e no meio natural. Essa intensa urbanização evidenciada pelo aumento da concentração da população nas cidades, requer dos gestores públicos um maior planejamento no âmbito urbano para absorver a crescente demanda por estruturas e serviços.

Segundo Mascaró (2009), o clima urbano é considerado um sistema que abrange o clima de um dado espaço terrestre e sua urbanização. Nesse sentido, fatores como as atividades humanas, o crescimento da frota de veículos motorizados, o aumento de superfícies pavimentadas e a diminuição de áreas verdes contribuem para as transformações verificadas no clima das cidades (ALMEIDA; BARBIRATO, 2004).

Em virtude disto, estudos da área de climatologia buscam avaliar a influência do desenho urbano na qualidade ambiental dos espaços, a fim de investigar a relação das massas edificadas com os elementos climáticos. Porém, segundo Landsberg (2006), é difícil mensurar o quanto uma aglomeração urbana impacta o clima de um determinado território, visto que grande parte dos sítios possuem um conjunto de condicionantes climáticas muito específicas e seus efeitos podem progredir gradativamente.

Conforme discorrem Monteiro e Mendonça (2003), os estudos de monitoramento do clima podem tornar o processo de planejamento urbano mais eficiente, uma vez que permitem avaliar os aspectos ambientais e territoriais da cidade. Tais trabalhos são importantes não só pelo acompanhamento climático, mas, principalmente, pela possibilidade de supervisão dos impactos oriundos do processo de urbanização. Desse modo, os estudos podem auxiliar gestores urbanos na tomada de decisões quanto ao planejamento das cidades.

O município de Vila Velha pertencente ao Estado do Espírito Santo (ES), localiza-se no litoral da Região Sudeste do Brasil e possui clima tropical úmido (ESPÍRITO SANTO, s.d.). Em 2020 e nos anos anteriores, vem sendo alvo de novos investimentos imobiliários e encontra-se em um processo de expansão territorial no qual destaca-se a ocupação das áreas próximas à orla marítima. Neste sentido, o objetivo deste trabalho consiste em avaliar a possível influência da verticalização, presente em edificações da orla de Vila Velha, no microclima local e na sensação térmica dos transeuntes dos bairros próximos a este adensamento.

\section{METODOLOGIA}

A área de análise situa-se em Vila Velha/ES, a $20^{\circ} 19^{\prime} 48^{\prime \prime}$ de latitude sul e $40^{\circ} 17^{\prime} 31^{\prime \prime}$ de latitude oeste (VILA VELHA, 2013a). Com um território de $209.965 \mathrm{~km}^{2}$ de extensão, o município possui uma população de 414.586 habitantes. Conforme identificado na Figura 1, Vila Velha é um dos sete municípios que compõem a Região Metropolitana da Grande Vitória (RMGV). Estima-se que seja o segundo município mais populoso da RMGV, atrás apenas do município de Serra (IBGE, 2010).

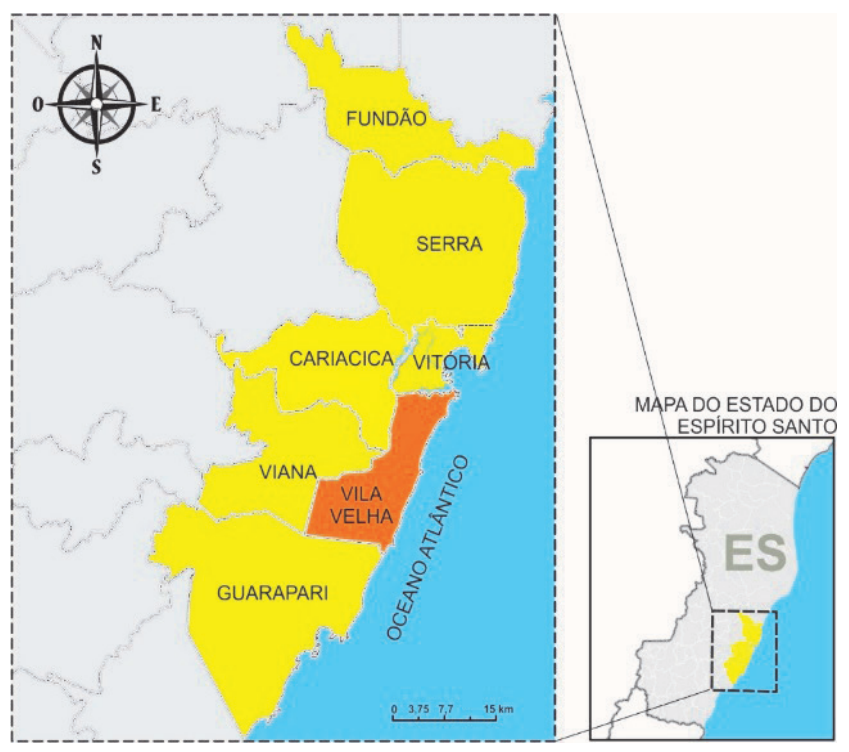

Figura 01 - Região Metropolitana da Grande Vitória Fonte: elaborado pelas autoras.

O município de Vila Velha é composto por noventa e dois bairros, distribuídos em cinco regiões administrativas instituídas pela Lei municipal 4.707 de 10 de dezembro de 2008 (VILA VELHA, 2013b). É pertinente ressaltar que o processo de ocupação do território, desde meados da década de 1970, já esboçava uma valorização dos loteamentos existentes próximos à orla (CHALHUB, 2010). Cerca de cinquenta anos depois, este município encontra-se com uma faixa litorânea predominantemente verticalizada, e cujo mercado imobiliário aponta a tendência de intensificação desta característica.

Partindo disso, o trabalho foi desenvolvido em três etapas principais, cada uma contendo um conjunto de procedimentos específicos. Na primeira etapa, foi realizada uma revisão bibliográfica no tema da pesquisa, cuja base teórica norteou a seleção do estudo de caso. Os bairros selecionados para estudo tiveram como principal critério de escolha a sua característica morfológica, visto que a presente pesquisa teve como objetivo investigar a influência da verticalização presente em edificações da orla de Vila Velha no microclima urbano. Prezou-se também pela escolha de áreas situadas em ambientes de características físico-ambientais semelhantes e sujeitas à interferência dos mesmos fenômenos climáticos. 
No intuito de garantir uma análise eficiente da presença da verticalização como fator de interferência no microclima urbano, buscou-se englobar no recorte de estudo tanto bairros já verticalizados quanto bairros onde ainda não se observa o processo de verticalização. Para definição da poligonal de estudo foram considerados os limites territoriais estabelecidos pela Prefeitura Municipal de Vila Velha. Ressalta-se que houve a preocupação em incorporar áreas situadas na orla marítima e áreas de bairros posteriores à faixa litorânea. Tal ação foi realizada com o objetivo de avaliar o possível efeito da verticalização como "barreira física" para penetração dos ventos marítimos no território e, consequentemente, sua influência na ambiência urbana.

Assim, foram selecionados os seguintes bairros do município de Vila Velha para incorporação do recorte de estudo: Praia de Itaparica, Praia de Gaivotas, Jockey de Itaparica e Coqueiral de Itaparica. Desse modo, obteve-se a poligonal apresentada na Figura 2.
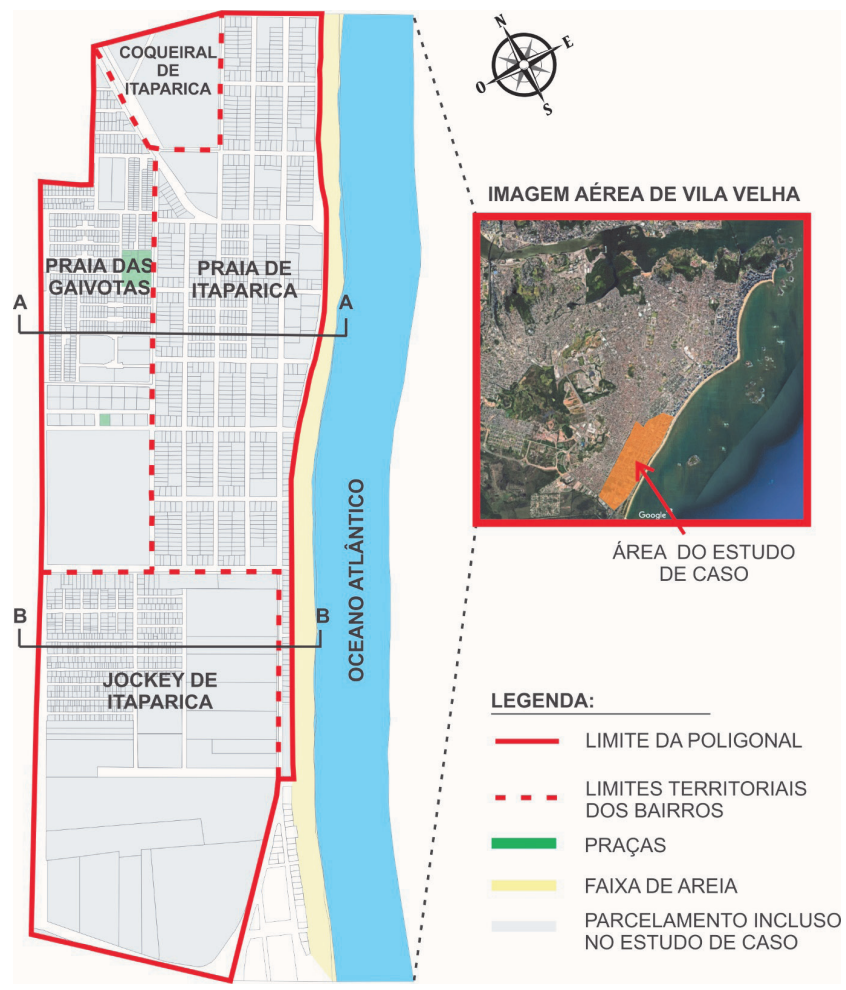

Figura 02 - Poligonal do estudo de caso Fonte: elaborado pelas autoras.

Embora os quatro bairros selecionados possuam forte carácter residencial, há disparidades no que diz respeito à sua morfologia. Vale ressaltar que a pesquisa não tem por objetivo qualificar cada variação morfológica ou classificá-las, mas sim, verificar a relação destas quanto à distribuição dos ventos locais e, consequentemente, sua influência no conforto térmico dos transeuntes.
O bairro Praia de Itaparica está situado na orla marítima e se destaca pelo número de empreendimentos em construção. Ao longo de sua extensão é possível identificar uma tendência de aumento do número de pavimentos conforme a aproximação com o litoral. Principalmente nas primeiras quadras posteriores à faixa litorânea há predominância de edificações com quinze ou mais pavimentos.

O bairro Praia das Gaivotas está localizado em uma área posterior ao bairro Praia de Itaparica. O primeiro bairro apresenta forte caráter horizontal, no qual se observa, em sua maioria, edificações de um a três pavimentos e poucos edifícios com gabarito superior a cinco pavimentos.

Na figura 3, evidencia-se a disparidade da escala construtiva existente entre os bairros Praia de Itaparica e Praia das Gaivotas.

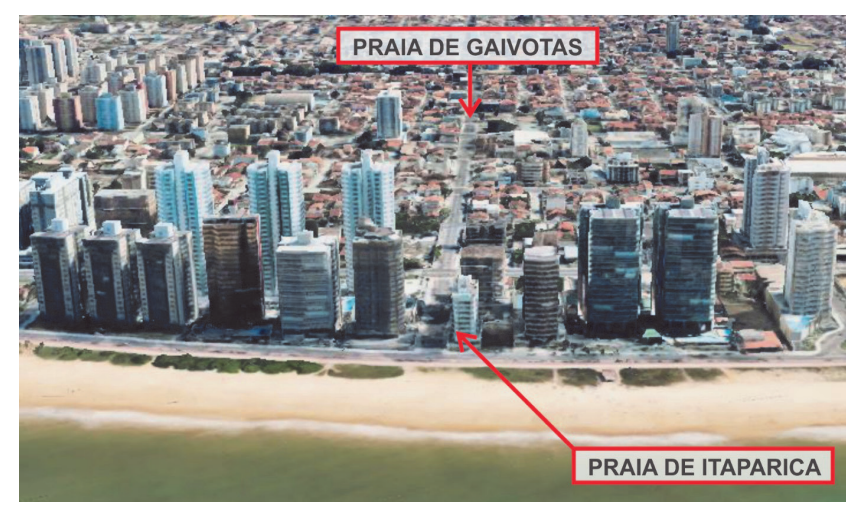

Figura 03 - Disparidade da escala construtiva entre os bairros Praia das Gaivotas e Praia de Itaparica Fonte: Adaptado do Google Earth (2017).

No bairro Jockey de Itaparica destaca-se a grande quantidade de lotes sem construções, principalmente nas áreas próximas à orla. Já as quadras mais afastadas da faixa litorânea, possuem o mesmo caráter de horizontalidade observado no bairro Praia das Gaivotas. A área da poligonal referente ao bairro Coqueiral de Itaparica consiste em um único condomínio residencial, cujas edificações possuem quatro pavimentos. Esta área foi incorporada ao recorte de estudo devido à possível interferência de suas construções na distribuição dos ventos locais.

Na segunda etapa da pesquisa, foram definidos os métodos de coleta dos dados e os critérios para escolha dos pontos de aferição das variáveis climáticas. A metodologia empregada utilizou a aferição simultânea dos pontos de monitoramento, cujo método foi adotado por possibilitar uma avaliação comparativa dos dados obtidos no levantamento. Conforme observado na Figura 4, os pontos de verificação foram organizados por eixos de análise, elaborados a partir de um alinhamento perpendicular à praia, no qual denominou-se: Trecho A (Praia de Itaparica -Praia de Gaivotas) e Trecho B (Jockey de Itaparica). 


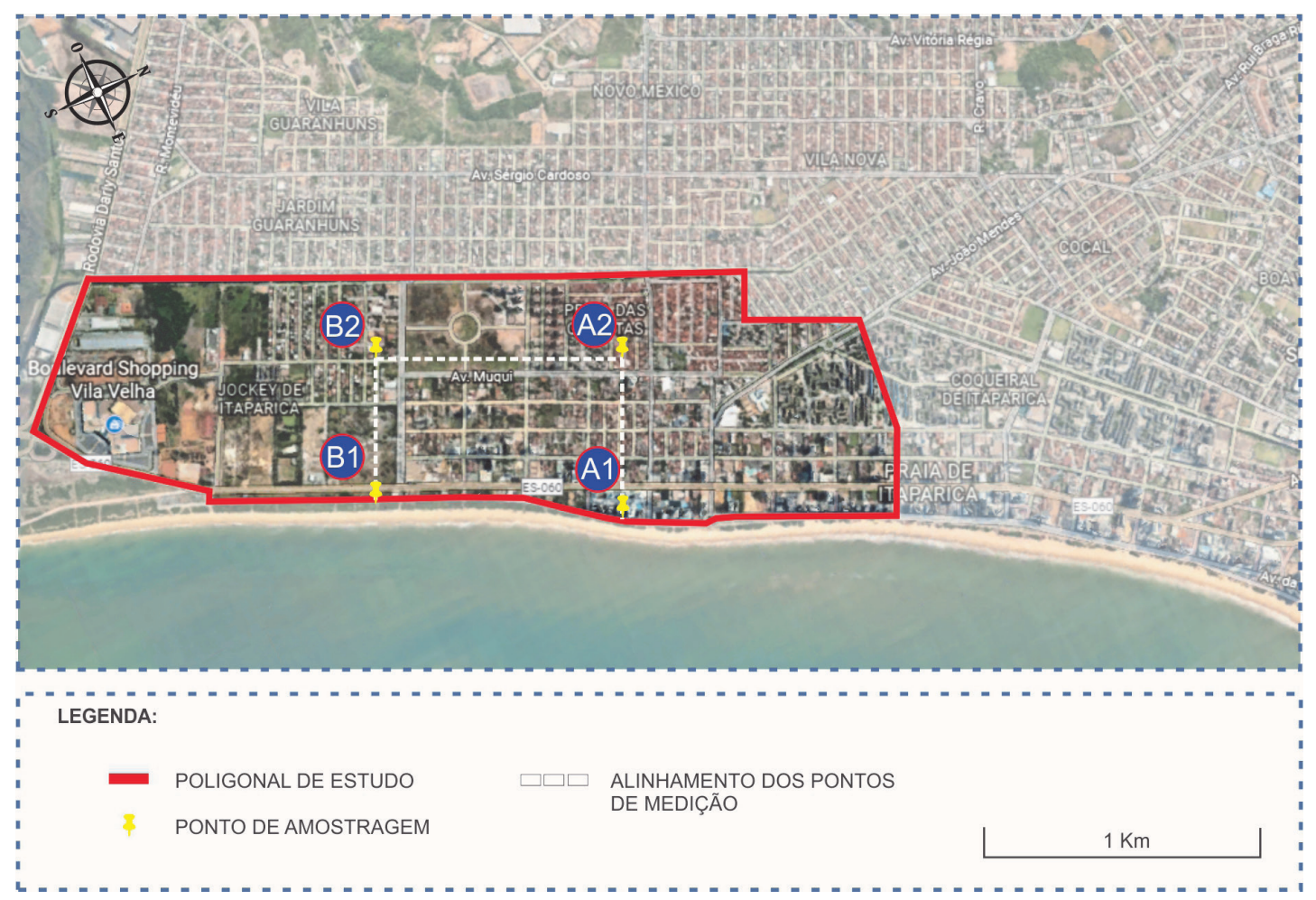

Figura 04 - Delimitação dos pontos de monitoramento

Fonte: elaborado pelas autoras.

A quantidade de pontos de monitoramento foi estabelecida em função do número de equipamentos disponíveis para execução da medição. Desse modo, foram delimitados 4 pontos no total e, para facilitar a organização da coleta de dados, optou-se por numerar como 1 os pontos situados no calçadão da orla e 2 os pontos localizados no interior dos bairros. Para a locação dos pontos foram considerados os seguintes critérios: (i) segurança; (ii) fluxo de circulação de pessoas (em virtude da aplicação dos questionários); e (iii) viabilidade (em relação ao deslocamento da equipe).

O monitoramento foi realizado na primavera, no dia 22 de outubro de 2017 e seguiu os procedimentos descritos a seguir. Em cada ponto de monitoramento foi montada uma miniestação meteorológica composta por 01 tripé, 01 abrigo meteorológico, 01 termo-higro-anemômetro e 01 HOBO data logger. Para evitar efeitos de distorção dos dados, procurou-se posicionar o conjunto sobre superfície plana, fora de áreas sombreadas e a uma distância mínima de 2,00 m de obstruções como, por exemplo, construções ou vegetação.

Além disso, foi estabelecido um padrão de coleta de dados a fim de evitar o comprometimento da pesquisa devido a interferências no processo de medição. Desse modo, os aparelhos data logger foram posicionados a uma altura de 1,10 $\mathrm{m}$ do solo, enquanto os anemômetros foram locados com a ventoinha à 1,50 $\mathrm{m}$ do solo. Destaca-se ainda que as miniestações foram posicionadas em função da direção predominante do vento no dia do monitoramento, sendo tal dado obtido a partir do Instituto Nacional de Meteorologia (INMET).

Tendo em vista que não é recomendável a exposição do aparelho data logger à radiação solar direta durante a execução da medição, utilizou-se um abrigo meteorológico constituído de pratos de isopor para proteção do equipamento. Pela impossibilidade de adquirir quatro aparelhos termo-higro-anemômetro iguais, optou-se por utilizar os equipamentos de mesma marca nos pontos de monitoramento de características físico-climáticas semeIhantes. Assim, os termo-higro-anemômetros do modelo AVM-05 da marca Prova Instruments foram posicionados nos pontos localizados na orla de Praia de Itaparica (A1 e B1), enquanto os termo-higro-anemômetros do modelo ITAN 700 da marca Instrutemp foram distribuídos nos pontos localizados no interior dos bairros de Jockey de Itaparica e Praia das Gaivotas (A2 e B2).

Foram consideradas as seguintes variáveis para análise: temperatura do $\operatorname{ar}\left({ }^{\circ} \mathrm{C}\right)$; umidade relativa do ar (\%); e velocidade dos ventos $(\mathrm{m} / \mathrm{s})$. Seguindo a recomendação da Organização Meteorológica Mundial (OMM) apresentada no Guide to Climatological Practices (WMO, 2011), foram definidos dois horários para registro, iniciados em todos os pontos de monitoramento simultaneamente, nos horários 
de $9 \mathrm{~h} 00$ e 15h00. A montagem das miniestações foi realizada 30 minutos antes dos horários preestabelecidos para registro e a amostragem climática teve uma duração total de 60 minutos em cada período (manhã e tarde).

Ainda referente ao procedimento de coleta, optou-se por realizar o monitoramento da velocidade dos ventos a partir de leituras contínuas com um tempo de amostragem de 15 minutos. Já em relação à temperatura e umidade do ar, foram configurados os equipamentos de modo a realizar o registro num intervalo de tempo de 1 minuto.

Em paralelo às medições das variáveis climáticas, nos pontos de monitoramento foram aplicados instrumentos de avaliação de percepção de conforto térmico dos transeuntes. O levantamento foi estruturado em forma de questionário composto por perguntas fechadas e o modelo adotado foi adaptado de Silva (2014), cuja estrutura divide-se em três partes: (i) registro da aplicação; (ii) dados individuais; e (iii) votos de sensação e preferência térmica. É importante destacar que foram considerados no questionário as condições em que a entrevista foi realizada, assim como o tipo de vestimenta e as atividades realizadas pelo transeunte antes da entrevista.

Para determinação da amostra, adotou-se como parâmetro o cálculo de amostragem aleatória disponibilizado por Santos (2017). Para efeito de cálculo, o universo da pesquisa foi composto pela soma das populações dos bairros analisados, tendo como referência os dados do Censo Demográfico de 2010 (IBGE, 2010). Assim, considerando uma população única de 34.019 habitantes obteve-se como amostra mínima um total de trinta questionários.

Definidos os métodos de coleta de dados a serem adotados pela pesquisa, por fim, na terceira etapa foi realizado o monitoramento das variáveis climáticas, bem como a análise dos dados coletados. Estes conteúdos serão apresentados a seguir.

\section{APLICAÇÕES E RESULTADOS}

Na Região Sudeste, a estação da primavera possui como características o aumento da temperatura e das chuvas (INMET, 2017a). Segundo os dados indicados pelo Clima Tempo (2017), no dia das medições foram previstos ventos fracos e moderados, com predominância nas direções norte/norte-nordeste (N/NNE). Quanto a condição do céu, no período matutino o mesmo apresentava-se claro e sem nuvem. Por sua vez, no período vespertino, o céu apresentava-se claro e parcialmente coberto por nuvens.

Num primeiro momento, foi observada uma pequena diferença nos valores obtidos no monitoramento das variáveis climáticas realizados pelo estudo de caso, quando comparado aos dados verificados pela estação meteorológica do INMET. Entende-se que este fenômeno pode ter ocorrido em virtude das diferenças morfológicas dos meios onde estão inseridos os pontos de monitoramento.

Nesse sentido, destaca-se que o posto meteorológico do INMET está localizado em área de baixa ocupação, enquanto o estudo de caso está inserido em uma área mais urbanizada. Desse modo, as características de superfície do solo, densidade construtiva, arborização, entre outros fatores contribuem para a configuração de dois microclimas diferenciados. Além disso, vale ressaltar que a estação meteorológica do INMET está posicionada a 25 metros de altitude, enquanto a área do estudo de caso está localizada ao nível do mar.

Conforme pode ser observado na Figura 5, a estação meteorológica do INMET está localizada em uma área bastante arborizada e com ausência significativa de superfície pavimentada. Em contrapartida, as áreas monitoradas pelo estudo de caso são, em sua maioria, pavimentadas e apresentam uma quantidade inferior de vegetação. Logo, entende-se que a variação climática verificada reitera a influência exercida pelas características morfológicas e construtivas sobre o microclima local.

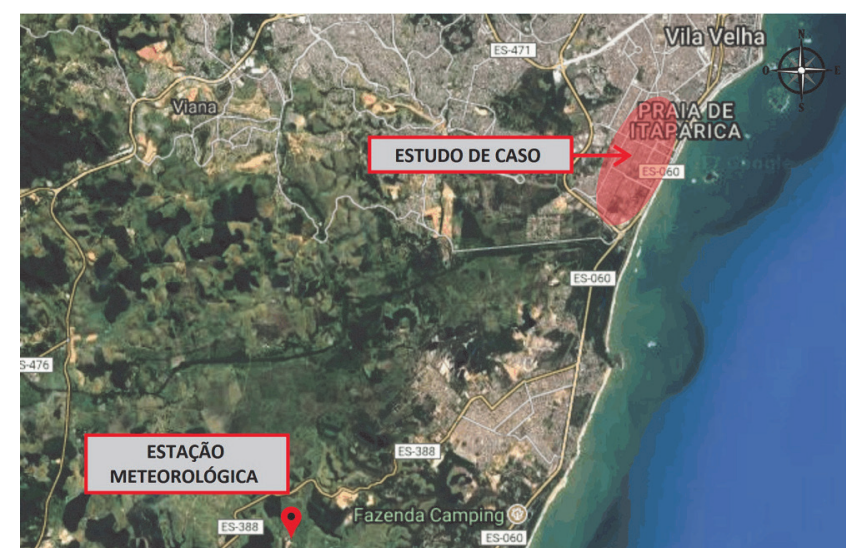

Figura 05 - Localização da estação meteorológica do INMET e do estudo de caso Fonte: adaptado de INMET (2017b).

Considerando os resultados coletados, percebe-se que os dados monitorados pelo posto meteorológico apresentaram menor variação de valores durante o período de medição, do que os dados aferidos nos pontos de análise do estudo de caso. Mediante este resultado, pode-se concluir que a dinâmica climática tende a ser mais instável em áreas sob maior influência urbana. É importante ressaltar que tais contrastes são desfavoráveis para o conforto térmico dos habitantes e, em situações mais graves, podem inclusive ocasionar impactos na sustentabilidade do ecossistema local. 
Conforme apresentado no Gráfico 01, considerando os valores instantâneos de temperatura do ar registrados na estação meteorológica, comparados à média dos valores de temperatura do ar obtidas nos quatro pontos de monitoramento no mesmo momento, observa-se que no primeiro caso registrou-se uma amplitude térmica de $2.6^{\circ} \mathrm{C}$, enquanto no segundo, obteve-se uma variação de $2.5^{\circ} \mathrm{C}$.

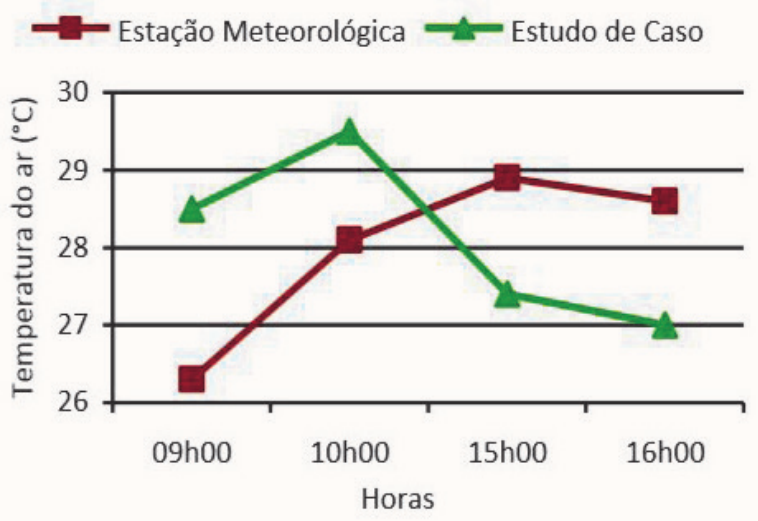

Gráfico 01 - Comparação dos valores de temperatura do ar entre a estação meteorológica e os pontos do estudo de caso

Fonte: elaborado pelas autoras.

Conforme demostrado no Gráfico 02, na estação meteorológica do INMET os dados relativos à umidade do ar foram mais estáveis do que os verificados no estudo de caso. Considerando o mesmo método de comparação adotado para análise da temperatura do ar, foram registradas variações de até $5 \%$ na estação meteorológica do INMET, que contrapõem os $14,5 \%$ registrados no estudo de caso.

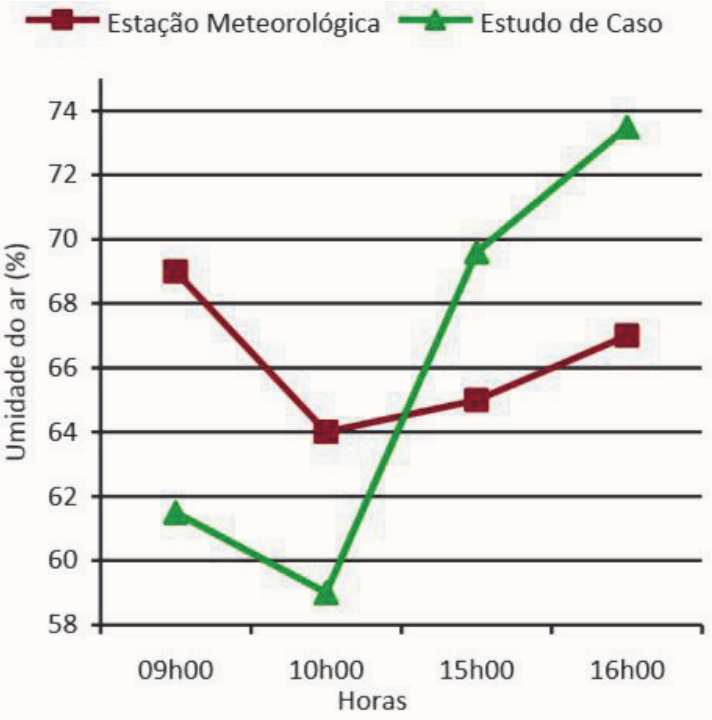

Gráfico 02 - Comparação dos valores de umidade do ar entre a estação meteorológica e os pontos do estudo de caso

Fonte: elaborado pelas autoras.
Devido a limitações dos equipamentos adotados pela pesquisa, apenas foi possível aferir a média da velocidade dos ventos nos pontos A2 e B2. Assim, optou-se por adotar como parâmetro de comparação a velocidade máxima dos ventos. Os resultados podem ser observados no Gráfico 03.

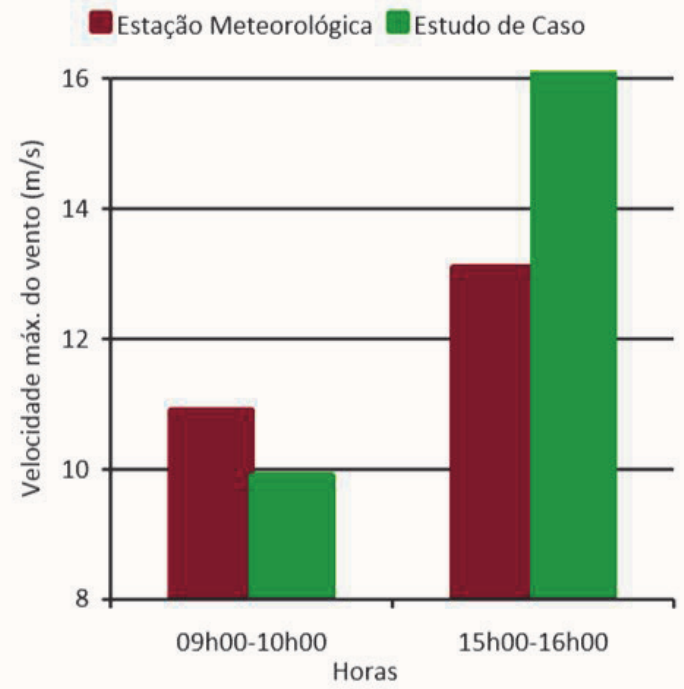

Gráfico 03 - Comparação dos valores de velocidade máxima do vento entre a estação meteorológica e os pontos do estudo de caso

Fonte: elaborado pelas autoras.

Embora se esperasse que no posto meteorológico a velocidade do vento fosse superior aos valores registrados no estudo de caso em função da altitude local, no período vespertino registrou-se o efeito contrário. Acreditase que este fenômeno possa ter ocorrido em virtude do aumento de vento na direção norte-nordeste ou da brisa marítima (correntes de ar características de regiões litorâneas), após às $15 \mathrm{~h} 00$.

\subsection{Análise da influência da verticalização pre- sente na orla marítima nas variáveis climáticas}

A partir dos resultados obtidos nos quatro pontos de medições, buscou-se a elaboração de análises globais e específicas por trechos de estudos (A e B). Em relação à velocidade dos ventos, foram utilizados como parâmetro de comparação os valores da máxima, mínima e a média registrada, já para a temperatura e umidade do ar, foram utilizados os valores instantâneos verificados na leitura.

O monitoramento referente à velocidade dos ventos evidenciou que em $75 \%$ das leituras realizadas no período da manhã, os pontos de medição inseridos na orla apresentaram velocidade superior aos pontos localizados no interior dos bairros. Como apresentado no Gráfico 04, no 
trecho A, onde a massa construtiva é maior, registrou-se o decaimento de até $3.8 \mathrm{~m} / \mathrm{s}$ da velocidade máxima do vento em relação aos pontos A1 (orla) e A2 (interior do bairro), no horário de 09h30 até 09h45.

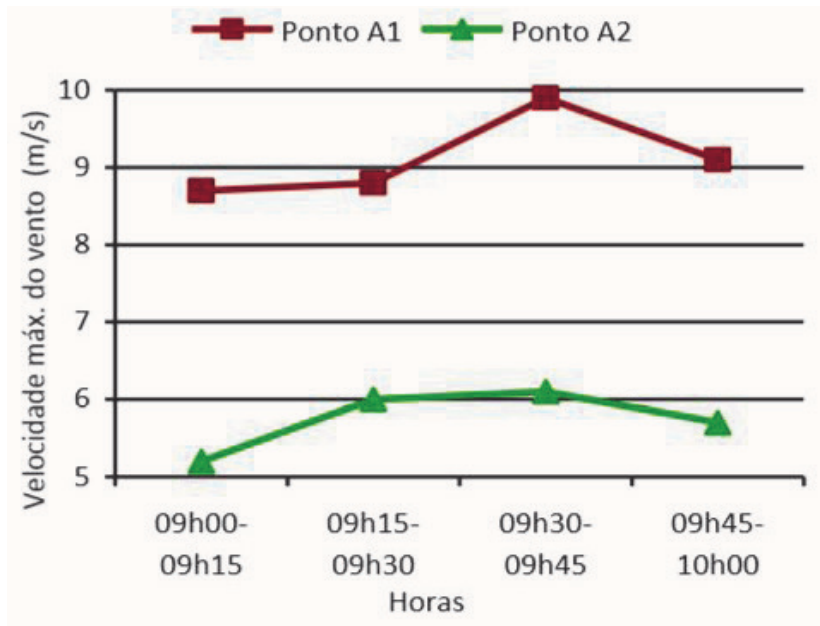

Gráfico 04 - Velocidade máxima do vento no trecho A no período matutino Fonte: elaborado pelas autoras.

Como observado no Gráfico 05 , no trecho B, onde não há muitas construções na orla, registrou-se o decaimento de até $0.7 \mathrm{~m} / \mathrm{s}$ da velocidade máxima do vento em relação aos pontos B1 (orla) e B2 (interior do bairro), no horário de 09h00 até 09h30. Após este horário, houve um aumento significativo da velocidade do vento no ponto B2, fenômeno que não foi observado no ponto B1. Uma possível explicação para o ocorrido se dá em virtude da canalização do vento ao longo das vias da malha urbana ou em decorrência da presença de ventos locais nas direções norte-nordeste.

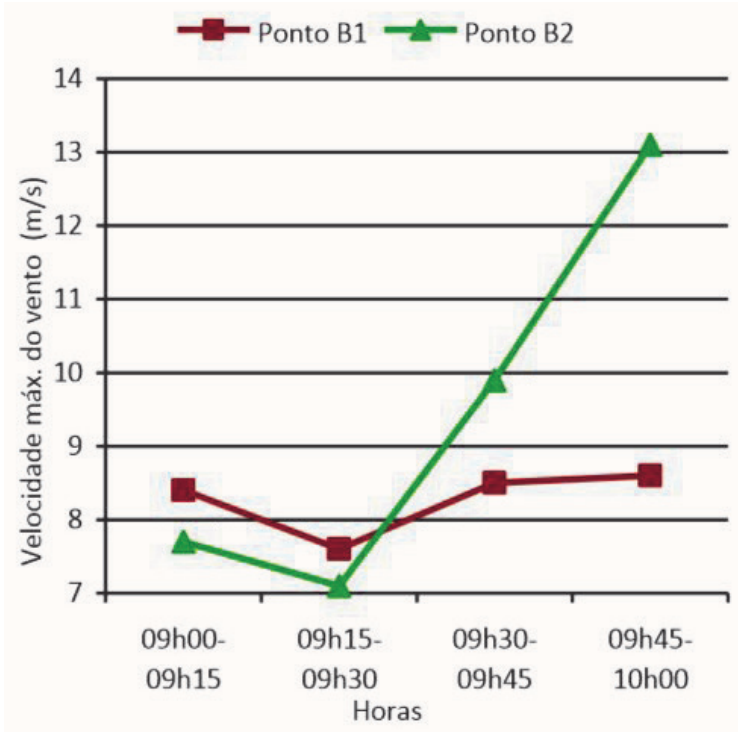

Gráfico 05 - Velocidade máxima do vento no trecho B no período matutino Fonte: elaborado pelas autoras.
Ao analisar os dados registrados no interior dos bairros no período matutino, destaca-se que os valores da velocidade máxima do vento em Jockey de Itaparica (B2) foram superiores aos do bairro de Praia das Gaivotas (A2). Ressalta-se também que, no primeiro bairro, 75\% das leituras de velocidade máxima do vento apresentaram médias de velocidade iguais ou superiores às registradas em Praia das Gaivotas.

No período vespertino, foi percebido o aumento significativo da velocidade dos ventos na área de estudo. Este fenômeno possibilitou a análise comportamental desta variável em diferentes condições climáticas. Foram registrados ventos com velocidade de até $16.1 \mathrm{~m} / \mathrm{s}$ (Gráfico 06), cujo valor, segundo a tabela de Beaufort corresponde à uma ventania moderada (ROMERO, 2000). Sob essas condições de rajadas fortes, no trecho $A$ registrou-se o ganho da velocidade dos ventos de até $1.1 \mathrm{~m} / \mathrm{s}$ do ponto $A 1$ para o ponto $A 2$.

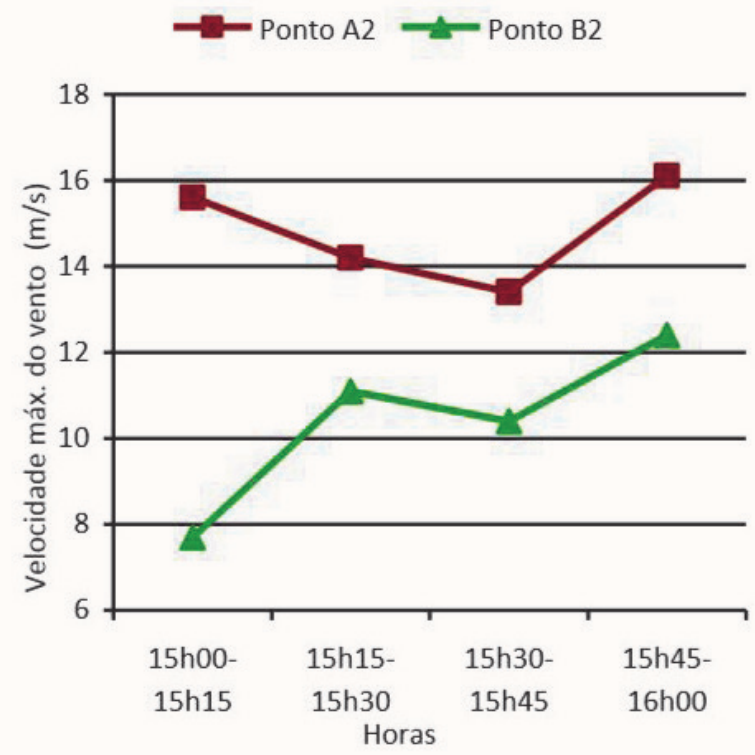

Gráfico 06 - Comparação da velocidade máxima do vento entre os pontos A2 e B2 no período vespertino Fonte: elaborado pelas autoras.

Segundo Romero (2000), o vento sob o efeito aerodinâmico de canalização pode aumentar a sua velocidade, entretanto, é preciso destacar que este efeito não ocorre de forma homogênea no território. Estes desvios ocasionados pelas barreiras de edificações tendem a direcionar a corrente de ar para as vias mais largas da malha urbana.

A partir disto, são formados canais de ventilação, cujo deslocamento é direcionado em função do posicionamento das construções ao longo da caixa viária. Apesar de este efeito provocar o aumento da velocidade dos ventos nas vias principais, por outro lado, outras áreas podem ficar mal ventiladas, podendo até mesmo criar uma região de sombra de vento. 
Como pode se observar no Gráfico 06 , todas as velocidades máximas registradas no período da tarde no ponto A2 (bairro Praia das Gaivotas) foram superiores aos valores registrados no ponto B2 (bairro Jockey de Itaparica). Considerando que no bairro de Jockey de Itaparica há poucas construções nas quadras próximas ao mar, este resultado reitera a interferência da verticalização sobre a ventilação urbana (efeito de canalização).

Conforme se apresenta no Gráfico 07 , em $75 \%$ das leituras a média de velocidade dos ventos foi superior no ponto B2. Apesar da velocidade máxima dos ventos registrar valores superiores no bairro de Praia das Gaivotas (A2), a partir dos resultados apresentados no Gráfico 06, percebe-se que este efeito não necessariamente agrega qualidade à ventilação do bairro visto que a comparação da média da velocidade dos ventos no período vespertino foi superior no ponto B2 em três dos quatros horários de registro. Nesse sentido, destaca-se que o cálculo da média possibilita uma caracterização mais próxima da condição real de ventilação de cada local.

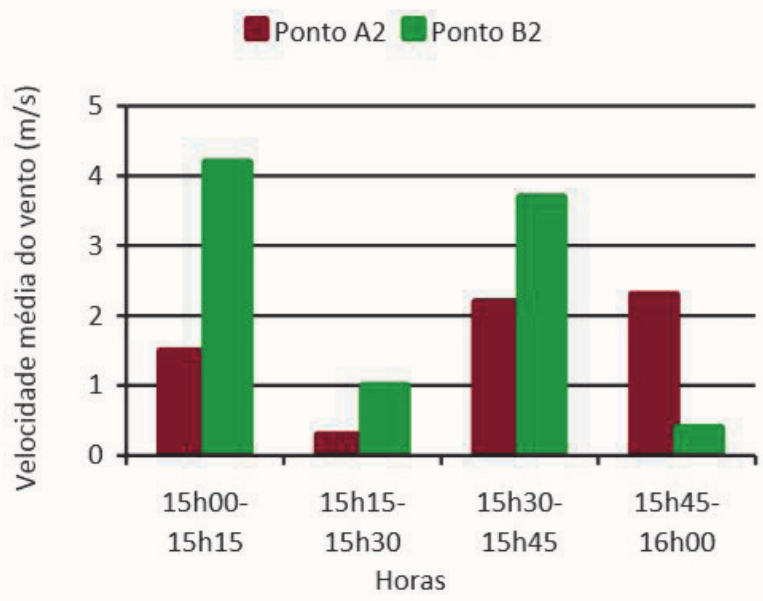

Gráfico 07 - Comparação dos valores de velocidade média do vento entre os pontos A2 e B2 no período vespertino

Fonte: elaborado pelas autoras.

Em relação à temperatura do ar, o Gráfico 08 apresenta a média aritmética dos valores instantâneos obtidos em cada ponto de análise. Conforme pode ser observado, no período da tarde houve uma maior variação da temperatura. Nos horários $15 \mathrm{~h} 00$ e $16 \mathrm{~h} 00$, nos pontos A1 e B1 (localizados na orla de Praia de Itaparica e Jockey de Itaparica, respectivamente) os valores registrados foram inferiores aos obtidos nos pontos A2 e B2 (localizados no interior dos bairros de Praia de Itaparica e Jockey de Itaparica, respectivamente). Destaca-se que este resultado coincidiu com o período (vespertino) no qual foi registrado o aumento substancial da velocidade dos ventos, demonstrando uma possível correlação entre as variáveis de velocidade do vento e temperatura do ar.

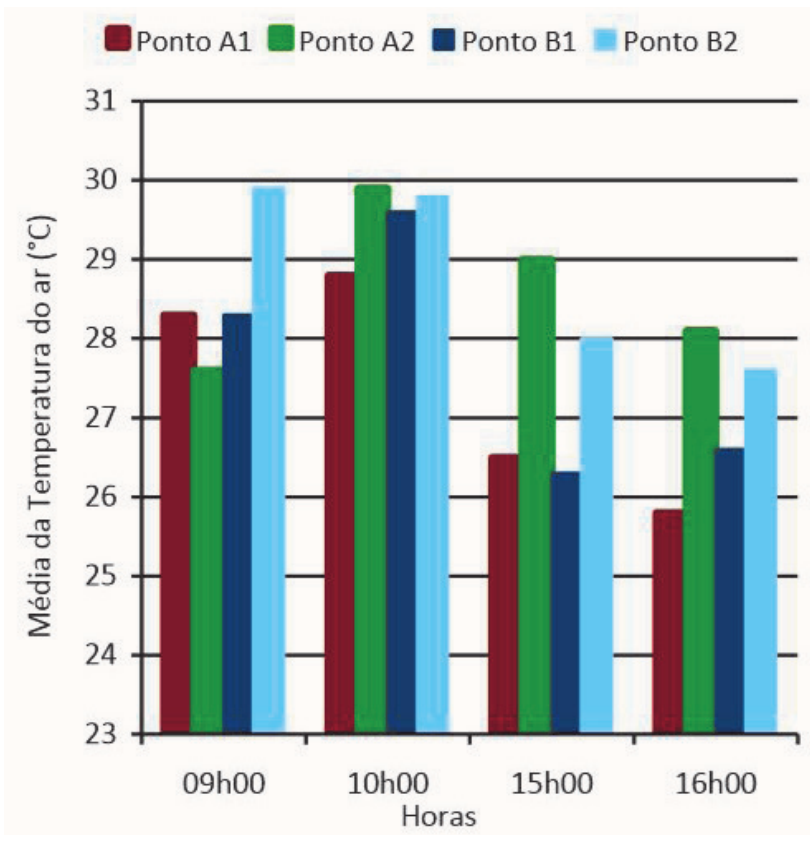

Gráfico 08 - Média da temperatura do ar registrada nos pontos de análise Fonte: elaborado pelas autoras.

Em relação à umidade do ar, o Gráfico 09 apresenta a média aritmética dos valores absolutos obtidos em cada ponto de análise. Conforme observado, os menores valores de umidade absoluta foram registrados no período da manhã, mesmo horário no qual foram registrados os maiores valores de temperatura do ar. Com exceção do ponto A2 (localizado no interior do bairro de Praia de Gaivotas), onde não foram registradas variações abruptas da média de temperatura do ar ao longo do monitoramento, nos demais pontos ficou evidente a relação inversamente proporcional entre as variáveis de temperatura do ar e umidade absoluta.

Durante o monitoramento, a maior diferença de umidade absoluta registrada foi de $11,8 \%$ entre os pontos B1 (localizado na orla de Jockey de Itaparica) e A2 (localizado no interior do bairro de Praia de Gaivotas), no horário de 15h00. O ponto B1 (localizado na orla de Jockey de Itaparica) apresentou a maior variação de umidade absoluta, um valor de 15,9\%, quando comparados os valores verificados às $9 \mathrm{~h} 00$ e $15 \mathrm{~h} 00$. Ainda em relação ao mesmo ponto, foi registrada a maior variação de temperatura do ar, um valor de $3^{\circ} \mathrm{C}$, quando comparados os valores verificados às $9 \mathrm{h00}$ e $15 \mathrm{~h} 00$. Tais resultados reiteram a correlação entre as variáveis de umidade do ar e temperatura do ar citadas anteriormente. 


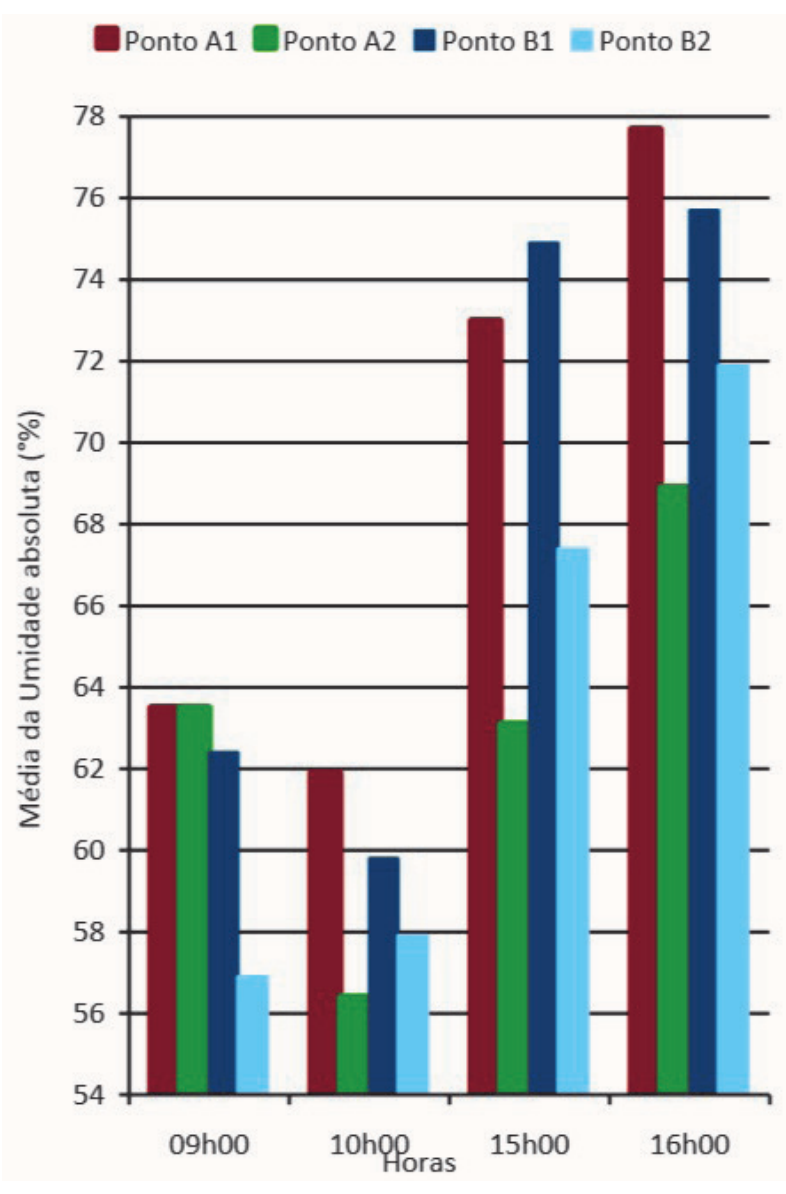

Gráfico 09 - Média da umidade absoluta registrada nos pontos de análise Fonte: elaborado pelas autoras.

\subsection{Avaliação de percepção da sensação térmi- ca dos transeuntes}

Conforme se apresenta na Tabela 01, para a avaliação de percepção da sensação térmica foram aplicados 66 questionários no estudo de caso, cujo valor é superior à amostra mínima estabelecida na metodologia do trabalho.

\begin{tabular}{|l|l|l|l|}
\hline Ponto A1 & Ponto B1 & Ponto A2 & Ponto B2 \\
\hline 21 & 12 & 17 & 16 \\
\hline
\end{tabular}

Tabela 01 - Número de entrevistados por ponto de monitoramento

Fonte: elaborado pelas autoras.

A princípio, buscou-se estipular uma quantidade mínima de aplicações de questionários para cada um dos pontos de análise, no intuito de garantir um valor considerável de respostas para a comparação dos resultados. Houve a preocupação em caracterizar o tipo de atividade que o entrevistado estava realizando anteriormente à aplicação do questionário (Tabela 02), bem como discriminar as condições ambientes nas quais ocorreram as entrevistas, visto que ambos os fatores interferem na percepção de conforto térmico do indivíduo.

\begin{tabular}{|c|c|c|c|c|c|c|}
\hline \multicolumn{7}{|c|}{ Análise dos entrevistados por atividade } \\
\hline 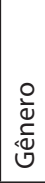 & 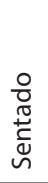 & 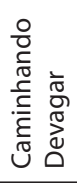 & $\begin{array}{l}\frac{0}{0} \\
\frac{\pi}{0} \\
\frac{0}{0} \\
\stackrel{0}{0} \\
\frac{0}{\varepsilon} \\
\underline{w}\end{array}$ & 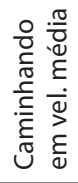 & 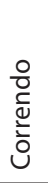 & 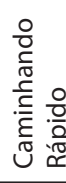 \\
\hline $\mathrm{F}$ & 05 & 19 & 07 & --- & --- & 01 \\
\hline M & --- & 20 & 07 & 05 & --- & 02 \\
\hline
\end{tabular}

Tabela 02 - Caracterização dos entrevistados por atividade previa ao questionário Fonte: elaborado pelas autoras.

Segundo Barbirato, Souza e Torres (2016), a avaliação do conforto térmico humano varia não só em decorrência dos aspectos relacionados aos espaços urbanos, mas também, em função de condições inerentes aos indivíduos, por exemplo: metabolismo, aspectos cognitivos, taxas de sudação, efeitos culturais, entre outros. Alguns estudiosos do conforto térmico urbano, como por exemplo, Fanger (1970), Givoni e Noguchi (2000), estabeleceram índices de conforto para áreas externas a partir de pesquisas realizadas. Entretanto, pela insuficiência de equipamentos para monitoramento das variáveis climáticas necessárias nos cálculos dos índices, a pesquisa adotou como parâmetro de conforto as condições relatadas nas respostas individuais dos entrevistados.

Em relação à percepção da sensação térmica no período da manhã, nos quatro pontos de monitoramento, a maioria dos entrevistados relataram se sentir bem. No que diz respeito aos pontos A1 e B1 (localizados na orla de Praia das Gaivotas e Jockey de Itaparica), 50\% dos respondentes afirmaram estar bem, 19\% relataram estar com um pouco de calor, $25 \%$ afirmaram sentir calor e $6 \%$ alegaram estar com muito calor (Gráfico 10).

No que diz respeito aos pontos A2 e B2 (localizados no interior dos bairros de Praia das Gaivotas e Jockey de Itaparica), $75 \%$ dos respondentes afirmaram estar bem, $13 \%$ relataram estar com calor e $12 \%$ afirmaram sentir muito calor (Gráfico 10).

No período da tarde, nos pontos A1 e B1 (localizados na orla de Praia das Gaivotas e Jockey de Itaparica), $64 \%$ dos entrevistados afirmaram estar bem em relação a sensação térmica, $12 \%$ relataram estar com um pouco de frio, $12 \%$ afirmaram estar com frio, $6 \%$ relataram sentir um pouco de calor e $6 \%$ afirmaram estar com calor. Estes resultados podem ser vistos no Gráfico 11.

Em relação aos pontos A2 e B2 (localizados no interior dos bairros de Praia das Gaivotas e Jockey de Itaparica), $29 \%$ dos entrevistados afirmaram estar bem em relação a sensação térmica, $47 \%$ relataram estar com muito calor e $24 \%$ afirmaram estar com calor (Gráfico 11). 


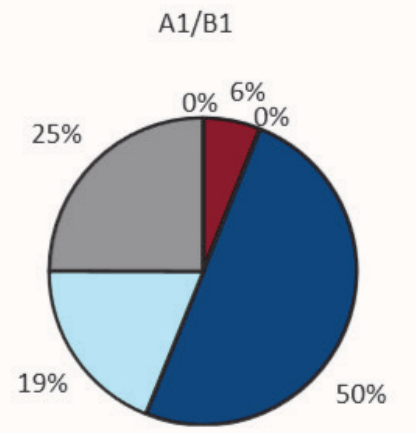

口Com muito calor

$\square$ Com um pouco de frio

Bem, nem frio nem calor

$\mathrm{A} 2 / \mathrm{B} 2$

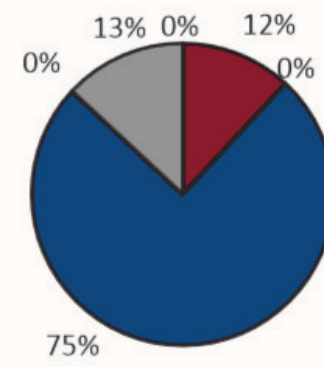

$\square$ Com um pouco de calor

$\square$ Com calor

$\square$ Com frio

Gráfico 10 - Percepção da sensação térmica dos transeuntes no período da manhã Fonte: elaborado pelas autoras.

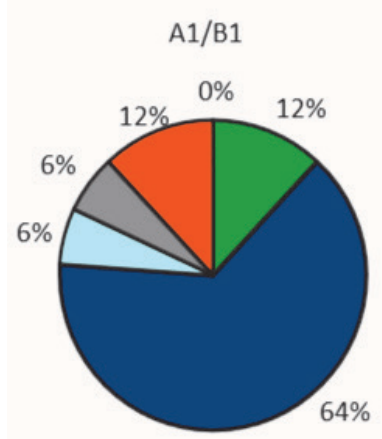

A2/B2

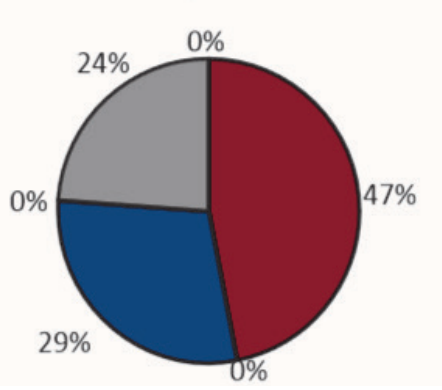

Gráfico 11 - Percepção da sensação térmica dos transeuntes no período da tarde Fonte: elaborado pelas autoras.

Com relação ao modo como os entrevistados gostariam de estar se sentindo no momento da entrevista, no período da manhã nos pontos A1 e B1 (localizados na orla de Praia das Gaivotas e Jockey de Itaparica), 69\% dos respondentes acharam que não era necessário haver alteração na condição climática e 31\% afirmaram preferir que estivesse um pouco mais frio. Estes resultados podem ser vistos no Gráfico 12.

Ainda no período matutino, nos pontos A2 e B2 (localizados no interior dos bairros de Praia das Gaivotas e Jockey de Itaparica), 69\% dos respondentes acharam que não era necessário haver alteração na condição climática, 25\% relataram preferir que estivesse um pouco mais frio e $6 \%$ afirmaram preferir que estivesse mais frio (Gráfico 12).
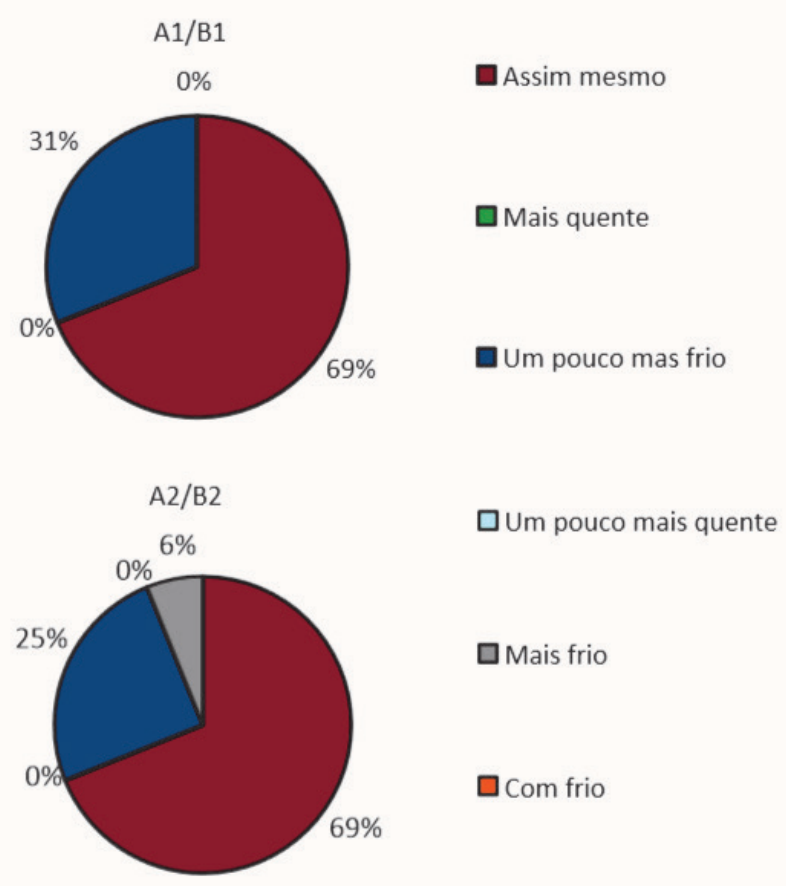

Gráfico 12 - Preferência da sensação térmica dos transeuntes no período da manhã Fonte: elaborado pelas autoras.

No que diz respeito à preferência da sensação térmica, no período da tarde nos pontos A1 e B1 (localizados na orla de Praia das Gaivotas e Jockey de Itaparica), 75\% dos respondentes acharam que não era necessário haver alteração na condição climática, $6 \%$ afirmaram preferir que estivesse mais quente, $13 \%$ relataram preferir que estivesse um pouco mais frio e $6 \%$ afirmaram preferir que estivesse um pouco mais quente. Estes resultados podem ser vistos no Gráfico 13.

Em relação aos pontos A2 e B2 (localizados no interior dos bairros de Praia das Gaivotas e Jockey de Itaparica), 35\% dos respondentes acharam que não era necessário haver alteração na condição climática, 30\% relataram preferir que estivesse um pouco mais frio e 35\% afirmaram preferir que estivesse mais frio (Gráfico 13). 


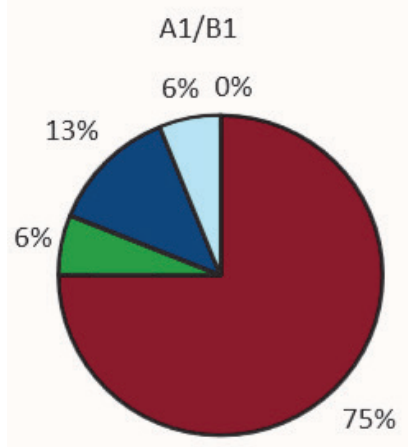

$\square$ Mais quente

Um pouco mas frio

A2/B2

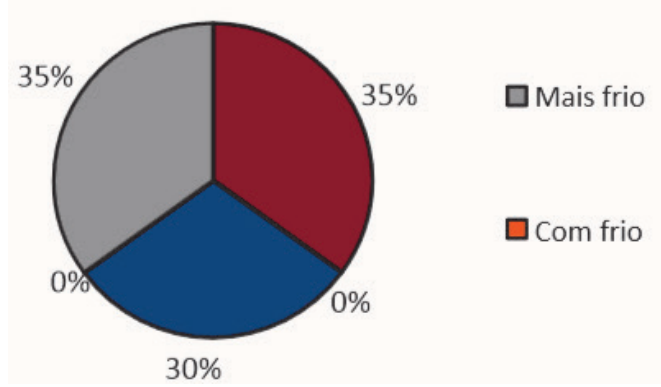

Gráfico 13 - Preferência da sensação térmica dos transeuntes no período da tarde Fonte: elaborado pelas autoras.

Com relação à ventilação, no período da manhã nos pontos A1 e B1 (localizados na orla de Praia das Gaivotas e Jockey de Itaparica), 75\% dos entrevistados classificaram o ambiente como ventilado, $12 \%$ classificaram o ambiente como estável e 13\% afirmaram que o ambiente estava com muito vento. Estes resultados apresentam-se no Gráfico 14.

Neste mesmo período, nos pontos A2 e B2 (localizados no interior dos bairros de Praia das Gaivotas e Jockey de Itaparica), 25\% dos entrevistados classificaram o ambiente como ventilado, $50 \%$ classificaram o ambiente como estável e $25 \%$ afirmaram que o ambiente estava com muito vento (Gráfico 14).

Com relação à ventilação, no período da tarde nos pontos A1 e B1 (localizados na orla de Praia das Gaivotas e Jockey de Itaparica), 18\% dos entrevistados classificaram o ambiente como ventilado, $6 \%$ classificaram o ambiente como estável e $76 \%$ afirmaram que o ambiente estava com muito vento. Estes resultados apresentam-se no Gráfico 15.

Ainda no período da tarde, nos pontos A2 e B2 (localizados no interior dos bairros de Praia das Gaivotas e Jockey de Itaparica), 18\% dos entrevistados classificaram o ambiente como ventilado, 35\% classificaram o ambiente como estável e $47 \%$ afirmaram que o ambiente estava com muito vento (Gráfico 15).

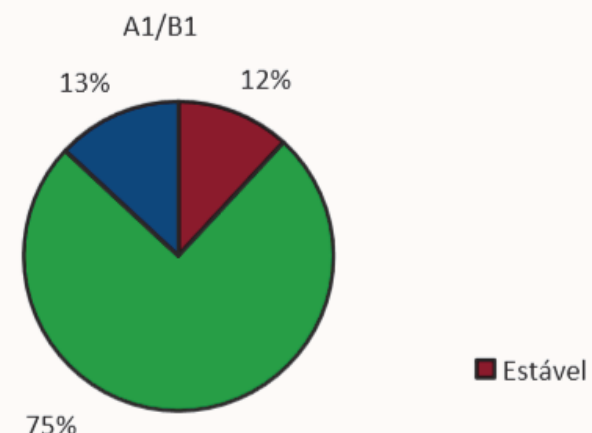

A2/B2

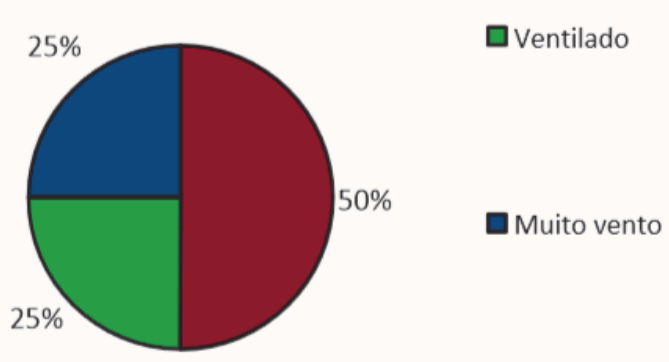

Gráfico 14 - Percepção da ventilação no período da manhã Fonte: elaborado pelas autoras.
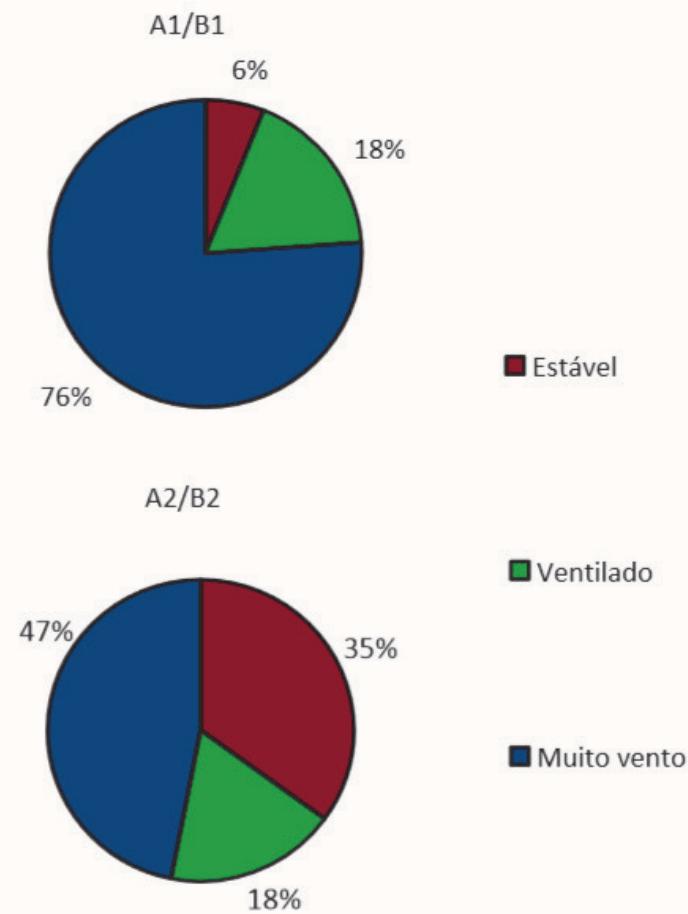

Gráfico 15 - Percepção da ventilação no período da tarde Fonte: elaborado pelas autoras.

Em ambos os períodos de monitoramento, foi verificado que a maioria dos entrevistados estavam confortáveis em relação a sensação térmica, apenas no período da tarde a maioria dos entrevistados nos pontos A2 e B2 (localizados no interior dos bairros de Praia de Itaparica 
e Jockey de Itaparica) relataram sentir calor. Estes resultados influenciaram diretamente os votos de preferência térmica dos transeuntes. Destaca-se que apenas no período da tarde nos pontos A2 e B2, foi percebido um maior equilíbrio entre as diferentes opções de respostas.

Torna-se oportuno salientar que ao analisar o trecho A, no período da manhã, foi verificado que no ponto A1 (localizado na orla de Praia das Gaivotas) todos os entrevistados afirmaram estar confortáveis em relação à sensação térmica, enquanto no ponto A2 (localizado no interior do bairro Praia das Gaivotas) quatro pessoas relataram estar desconfortáveis. A partir da associação destes resultados aos dados aferidos nas medições, foi observado que neste período a velocidade dos ventos no interior do bairro era inferior aos valores registrados na orla, além disso, os valores de temperatura do ar obtidos nesse mesmo ponto (A2) foram mais elevados. A partir destes resultados, pode-se concluir que a condição microclimática de cada ponto influenciou na sensação térmica dos transeuntes.

Em relação à ventilação, somente no período da tarde a maioria dos entrevistados afirmaram que o ambiente estava com muito vento. Conforme apresentado anteriormente, neste horário foi verificado o aumento da velocidade máxima do vento nos quatro pontos de monitoramento. Sabe-se que, em função do aumento da velocidade dos ventos, o processo de troca de calor pode se intensificar e, consequentemente, provocar o desconforto térmico do indivíduo pelo excesso de perda de calor. Neste contexto, as construções, além de modificarem os percursos naturais do vento, podem contribuir para alteração da sua velocidade.

\section{CONSIDERAÇÕES FINAIS}

A presente pesquisa teve por objetivo avaliar a possível influência da verticalização no microclima urbano e na sensação térmica. Os resultados obtidos contribuíram para elucidação da correlação entre o espaço construído, as variáveis climáticas e a percepção da sensação térmica do transeunte. Conforme observado, os aspectos inerentes ao desenho urbano contribuíram para a formação de diferentes microclimas nos recortes urbanos estudados. A partir da análise do comportamento das variáveis climáticas em diferentes horários, foi observado que estas apresentaram variações em função da localização dos pontos de monitoramento.

O monitoramento climático em ambientes de diferentes características morfológicas permitiu a comparação dos valores registrados e a análise dos efeitos provocados pela massa construtiva, bem como sua influência no conforto térmico dos transeuntes.
A verticalização das edificações presentes nas quadras da orla apresentou-se como principal efeito a barragem da ventilação, percebida a partir da redução da velocidade dos ventos no ponto posterior a orla. Foi verificado também o efeito de canalização do vento, evidenciado em função do aumento da velocidade dos ventos após a penetração da corrente de ar nas áreas verticalizadas.

Como discutido anteriormente, estes efeitos influenciam o microclima e, por vezes, podem resultar na perda de qualidade da ambiência local. Diferente do que ocorre quando este efeito é provocado intencionalmente no desenho urbano, no caso da área estudada, ele ocorreu como consequência das estruturas urbanas já consolidadas no recinto urbano.

Torna-se oportuno mencionar que a modificação da velocidade dos ventos em virtude da verticalização influenciou nos valores obtidos das demais variáveis climáticas monitoradas. Deste modo, pôde ser evidenciada a correlação destes elementos na formação do microclima local, assim como no conforto térmico dos transeuntes.

Tendo em vista o atual crescimento do município de Vila Velha e, principalmente, a forte tendência de verticalização das áreas litorâneas, este trabalho buscou contribuir com os novos estudos, no intuito de fornecer subsídios ao Plano Diretor Municipal - PDM para elaboração de diretrizes urbanas que visem garantir a qualidade ambiental para toda a população, residente na orla marítima ou não.

É importante salientar que a verticalização, quando controlada, não é prejudicial ao conforto ambiental em áreas urbanas. Conforme discorrem Acioly e Davidson (2011), quando planejada ela pode atuar como eficiente instrumento para controle de densidades urbanas, expansão da malha urbana, entre outros aspectos. O que foi avaliado na pesquisa são os efeitos ocasionados pelos diferentes gabaritos e tipos de organização espacial presentes na área de estudo. Este trabalho visa reforçar a importância de uma análise preliminar dos impactos provenientes da verticalização nas condições climáticas locais.

Apesar do aumento dos estudos relacionados à ambiência urbana, ainda há muito que se aprimorar nas pesquisas relacionadas à temática da climatologia urbana. Conforme evidenciado no decorrer da pesquisa, muitas vezes, os equipamentos e dados disponíveis são insuficientes para a realização de uma investigação mais detalhada.

A partir dos resultados obtidos na pesquisa, são apresentadas algumas sugestões para futuros trabalhos como, por exemplo: a análise de outras variáveis climáticas, a realização do monitoramento em diferentes estações do ano, a classificação das percepções de conforto térmico 
dos transeuntes segundo índices de conforto para ambientes externos e a realização de simulações computacionais com o objetivo de caracterizar a dinâmica climática em áreas urbanas.

\section{AGRADECIMENTOS}

As autoras agradecem o Laboratório de Conforto Ambiental da Faculdade Multivix-Vitória e o Laboratório de Planejamento e Projetos da Universidade Federal do Espírito Santo, por fornecerem os equipamentos necessários para a realização do monitoramento climático. Fica aqui expressa nossa gratidão a todos os colaboradores voluntários que acreditaram nessa pesquisa e se disponibilizaram para ajudar na execução das medições.

\section{REFERÊNCIAS}

ACIOLY, Cláudio; DAVIDSON, Forbes. Densidade urbana: um instrumento de planejamento e gestão urbana. 2. ed. Rio de Janeiro: Mauad, 2011.

ALMEIDA, E. M. de A.; BARBIRATO, G. M. A morfologia urbana como determinante de variações climáticas locais: estudo comparativo das orlas marítima e lagunar de Maceió - AL, 2004. Anais eletrônicos...I Conferência Latino-americana de Construção Sustentável X Encontro Nacional de Tecnologia do Ambiente Construído, São Paulo, SP, Brasil. Acesso em: 09 abr. 2018.

BARBIRATO, G. M.; SOUZA, L. C.; TORRES S. Clima e cidade: abordagem climática como subsídio para estudos urbanos. Maceió: EDUFAL, 2016. 201 p.

CHALHUB, Antônio. 0 imaginário da cidade no pacto socioambiental de um plano diretor municipal: o planejamento urbano e a lei em Vila Velha/ES. Vitória, 2010. 402 p.

CLIMA TEMPO. Previsão do tempo. Disponível em: <https://www.climatempo.com.br/brasil>. Acesso em: 22 out. 2017.

ESPÍRITO SANTO. Secretaria de Estado de Turismo. Geografia do Espírito Santo. (s.d.). Disponível em: $<$ http://descubraoespiritosanto.es.gov.br/pt/o-espirito-santo\#geografia>. Acesso em: 11 fev. 2019.

FANGER, P. O. Thermal Confort. New York: McGrawHill, 1973.

GIVONI, B., NOGUCHI, M. Issues in outdoor comfort research. In: International Conference on Passive and Low Energy Achitecture, 17, 2000, Cambridge. Proceedings...Cambridge: James \& James, 2000, p. $562-565$.

GOOGLE. Software Google Earth Pro. Estados
Unidos, 2017. Disponível em: <https://www.google. com.br/intl/pt-BR/earth/>. Acesso em: 10 nov. 2017.

IBGE, Instituto Brasileiro de Geografia e Estatística. Censo demográfico, 2010. Disponível em: <https:// cidades.ibge.gov.br/v4/brasil/es/vila-velha/panorama>. Acesso em: 08 jun. 2017.

INMET, Instituto Nacional de Meteorologia. Prognóstico climático de primavera. (2017a). Disponível em: <http://www.inmet.gov.br/portal/index.php? $r=$ noticia/visualizarNoticia\&id=112>. Acesso em: 03 out. 2017.

INMET, Instituto Nacional de Meteorologia. Estações automáticas. (2017b). Disponível em: < http://www. inmet.gov.br/portal/index.php?r=estacoes/estacoesAutomaticas>. Acesso em: 08 nov. 2017.

LANDSBERG, H. E. O clima das cidades. Revista do Departamento de Geografia, São Paulo [SP], v. 18, pp. 95-111, 2006. Disponível em: <http://www.revistas. usp.br/rdg/article/view/47269/51005>. Acesso em: 19 jun. 2017.

MASCARÓ, L.; MASCARÓ, J. J. Ambiência urbana - Urban Enviroment. 3. ed. Porto Alegre [RS]: Masquatro Editora, 2009. 200 p.

MONTEIRO, C. A. de F.; MENDONÇA, F. Clima Urbano. São Paulo: Contexto, 2003. 192 p.

ROMERO, Marta A. B. Princípios bioclimáticos para o

desenho urbano. 2. ed. Brasília: Editora Universidade de Brasília, 2000. 128 p.

SANTOS, G. E. de O. Cálculo amostral: calculadora online. Disponível em: <http://www.publicacoesdeturismo.com.br/calculoamostral/>. Acesso em: 15 out. 2017. SILVA, Fabiana Trindade da. Conforto do transeunte: a porosidade urbana como condicionante da ventilação. 121 f. Dissertação (Mestrado em Arquitetura e Urbanismo) - Universidade Federal do Espírito Santo, Vitória [ES], 2014.

VILA VELHA. Prefeitura Municipal. Perfil socioeconômico por bairros. Vila Velha, 2013a.

VILA VELHA. Prefeitura Municipal. Plano municipal de contingência. Vila Velha, 2013b.

WMO, World Meteorological Organization. Guide to climatological practices. 2011 ed. Genova: WNO, 2011. 117 p. 


\section{AUTORES}

ORCID: https://orcid.org/0000-0001-5278-1572

JULIANA SILVA ALMEIDA SANTOS | Universidade Federal do Espírito Santo | Arquitetura e Urbanismo | Vitória, Espírito Santo (ES) - Brasil | Correspondência para: Laboratório de Planejamento e Projetos, Av. Fernando Ferrari, 514, Sala 7 - Goiabeiras, Vitória - ES, CEP: 29075-910 | E-mail: juliana. arq1@gmail.com

ORCID: https://orcid.org/0000-0003-2221-1661

ALINE SILVA SAUER, M.Sc. | Faculdade Centro-Leste | Arquitetura e Urbanismo | Serra, Espírito Santo (ES) - Brasil | Correspondência para: Rodovia ES 010, Manguinhos, Serra - ES, CEP: 29173-087 | E-mail: alinesisa@hotmail.com

\section{COMO CITAR ESTE ARTIGO}

SANTOS, Juliana Silva Almeida; SAUER, Aline Silva. A Influência da Verticalização na Sensação Térmica Urbana: Estudo de Caso Em Vila Velha/ES. MIX Sustentável, [S.I.], v. 6, n. 4, p. 29-42, ago. 2020. ISSN 24473073. Disponível em:<http://www.nexos. ufsc.br/index.php/mixsustentavel>. Acesso em: dia mês. ano. doi:https://doi.org/10.29183/2447-3073. MIX2020.v6.n4.29-42. 